7. Tan L, Wang Q, Zhang D, Ding J, Huang Q, Tang YQ, Wang Q, Miao H. Lymphopenia predicts disease severity of COVID-19: a descriptive and predictive study. Signal Transduct Target Ther 2020;5:1-3.

8. Sun M, Yang J, Sun Y, Su G. Inhibitors of RAS might be a good choice for the therapy of COVID-19 pneumonia. Zhonghua Jie He He Hu Xi Za Zhi 2020;43:E014-E.

9. Mehta $P$, McAuley DF, Brown $M$, Sanchez $E$, Tattersall RS, Manson JJ. COVID-19: Consider cytokine storm syndromes and immunosuppression. Lancet 2020;395:1033-1034.
10. Koca E, Haznedaroglu IC, Uner A, Sayinalp N, Saglam AE, Goker H, Ozcebe Ol. Angiotensin-converting enzyme expression of the lymphoma-associated macrophages in the lymph nodes of Hodgkin's disease. J Natl Med Assoc 2007;99:1243-4, 1246-7.

11. Monteil V, Kwon H, Prado P, Hagelkrüys A, Wimmer RA, Stahl M, Leopoldi A, Garreta E, Hurtado Del Pozo C, Prosper F, Romero JP, Wirnsberger G, Zhang $H$, Slutsky AS, Conder R, Montserrat N, Mirazimi A, Penninger JM. Inhibition of SARS-CoV-2 infections in engineered human tissues using clinical-grade soluble human ACE2. Cell 2020;181:905-913.e7.

\title{
Hepatitis B Virus Reactivation under Ibrutinib Treatment in a Patient with Chronic Lymphocytic Leukemia
}

\author{
Kronik Lenfositik Lösemili Bir Hastada Ibrutinib Tedavisi Altında Hepatit B Virüsü \\ Reaktivasyonu
}

(1) Gülşen İskender ${ }^{1}$, (1) Dicle İskender 2 , (1) Mustafa Ertek ${ }^{1}$

${ }^{1}$ Dr. Abdurrahman Yurtaslan Ankara Oncology Training and Research Hospital, Clinic of Infectious Diseases and Clinical Microbiology, Ankara, Turkey ${ }^{2}$ Dr. Abdurrahman Yurtaslan Ankara Oncology Training and Research Hospital, Clinic of Hematology and Blood and Marrow Transplantation, Ankara, Turkey

To the Editor,

Immunosuppression in patients with hepatitis B virus (HBV) infection may result in viral reactivation. This risk is higher in patients with present than past HBV infection (hepatitis B surface antigen (HBsAg)-positive vs. HBsAg-negative, anti$\mathrm{HBc}$ positive) and in patients with hematological malignancies and related treatments $[1,2]$. Ibrutinib is a Bruton's tyrosine kinase inhibitor (TKI) indicated in the treatment of relapsed/ refractory chronic lymphocytic leukemia (CLL) [3]. The American Gastroenterological Association Institute categorized patients with past HBV infection treated with TKIs as having a moderate risk for HBV reactivation ( $\mathrm{HBV}$ ) (1\%-10\%). There is only a weak recommendation for routine viral prophylaxis for $\mathrm{HBV}$ in that guideline [2], whereas in the ECIL-5 guideline, there is no suggestion about the management of these patients [4]. Here we describe a case of HBVr under ibrutinib monotherapy in a patient with past HBV infection and relapsed/refractory CLL. A 58-year-old man was diagnosed with CLL. His HBV serology was compatible with past infection (Figure 1). According to existing guidelines [1,2], follow-up of liver enzymes, HBV serology, and HBV-DNA every 3 months was planned without antiviral

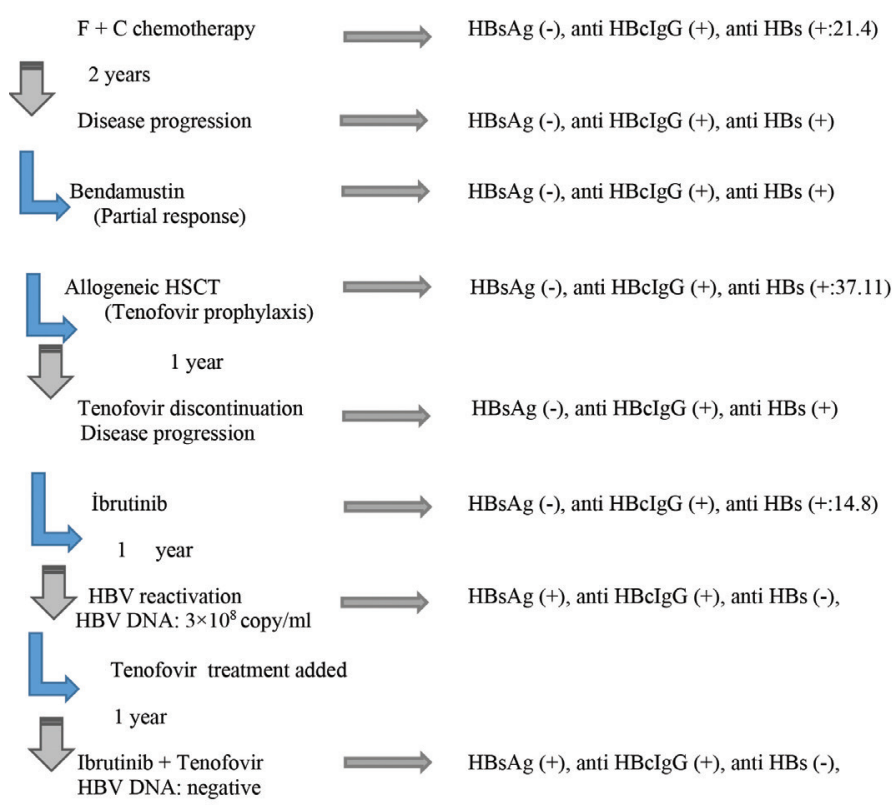

Figure 1. Summarized course of the disease.

HBsAg: Hepatitis B surface antigen. 
prophylaxis. Following first-line treatment with fludarabine and cyclophosphamide, the disease progressed, and bendamustine was started. He achieved a good partial response and allogeneic hematopoietic stem cell transplantation (HSCT) was performed under antiviral prophylaxis by tenofovir disoproxil at 245 $\mathrm{mg} /$ day. HBV serology prior to HSCT was as follows: $\mathrm{HBsAg}$ $(-)$, anti-HBc $\operatorname{lgG}(+)$, anti-HBs (+). Antiviral prophylaxis was discontinued 1 year after HSCT but disease progression was detected and ibrutinib was started at $420 \mathrm{mg} /$ day. At this time, the serological results did not change (Figure 1). One year later while he was still on ibrutinib treatment, HBV serology showed reactivation with $\mathrm{HBsAg}(+)$, anti-HBc $\operatorname{lgG}(+)$, anti-HBs (-), HBeAg (+), and HBV DNA of $3 \times 10^{3}$ copies $/ \mathrm{mL}$ that progressed to $1 \times 10^{8}$ copies $/ \mathrm{mL}$ over 30 days, with normal liver enzymes. Treatment with tenofovir disoproxil at $245 \mathrm{mg} /$ day was therefore initiated. HBV DNA levels decreased progressively and reached undetectable levels within 1 year. At the time of this report, he is on ibrutinib and tenofovir treatment with $\mathrm{HBsAg}(+)$, anti$\mathrm{HBC} \operatorname{lgG}(+)$, anti-HBs (-), HBeAg (+), and negative HBV DNA. The course of the disease is summarized in Figure 1.

Ibrutinib has B-cell signaling inhibitory activity that might be more potent than anti-CD20 monoclonal antibodies. $\mathrm{HBVr}$ in the case of chronic HBV carrier state or past HBV infection could be a potential complication of treatment with this agent [5]. In our patient, occurrence of HBVr 2 years after allogeneic HSCT and 1 year after ibrutinib makes ibrutinib the possible cause of reactivation. Because HBsAg positivity was considered as an exclusion criterion in ibrutinib clinical trials, no recommendation was provided in guidelines for the management of HBsAg (-)/anti-HBc (+) patients who are being treated with this agent [6]. Reports have been published since 2015 that emphasize the effect of ibrutinib on HBVr in patients with past HBV infection $[5,7,8]$. These reports along with our case emphasize the risk of $\mathrm{HBV}$ r secondary to ibrutinib use in $\mathrm{HBsAg}(-)$, anti-HBc (+) patients. In our opinion, there is a need for an international consensus to support the recommendation of antiviral prophylaxis against $\mathrm{HBVr}$ in this group of patients.

Keywords: Hepatitis B reactivation, Ibrutinib, Chronic lymphocytic leukemia

Anahtar Sözcükler: Hepatit B reaktivasyonu, ibrutinib, Kronik lenfositik lösemi
Informed Consent: Informed consent was obtained from the patient.

\section{Authorship Contributions:}

Medical Practices: G.i., D.í; Concept: G.i.., D.İ, M.E.; Design: G.i.., D.I, M.E.; Data Collection or Processing: G.I., D.I.; Analysis or Interpretation: G.I. D.I., M.E.; Literature Search: G.I.., D.I., M.E.; Writing: G.i.

Conflict of Interest: The authors of this paper have no conflicts of interest, including specific financial interests, relationships, and/or affiliations relevant to the subject matter or materials included.

\section{References}

1. Aygen B, Demir AM, Gümüş $M$, Karabay 0 , Kaymakoğlu S, Köksal AŞ, Köksal I, Örmeci N, Tabak F. Immunosuppressive therapy and the risk of hepatitis B reactivation: consensus report. Turk J Gastroenterol 2018;29:259-269.

2. Reddy KR, Beavers KL, Hammond SP, Lim JK, Falck-Ytter YT; American Gastroenterological Association Institute. American Gastroenterological Association Institute guideline on the prevention and treatment of hepatitis $B$ virus reactivation during immunosuppressive drug therapy. Gastroenterology 2015;148:215-219.

3. Varma G, Johnson TP, Advani RH. Bruton's tyrosine kinase inhibitors in chronic lymphocytic leukemia and lymphoma. Clin Adv Hematol Oncol 2016;14:543-554.

4. Mallet $V$, van Bömmel $F$, Doerig C, Pischke $S$, Hermine O, Locasciulli A, Cordonnier C, Berg T, Moradpour D, Wedemeyer H, Ljungman P; ECIL-5. Management of viral hepatitis in patients with haematological malignancy and in patients undergoing haematopoietic stem cell transplantation: recommendations of the 5th European Conference on Infections in Leukaemia (ECIL-5). Lancet Infect Dis 2016;16:606-617.

5. de Jésus Ngoma P, Kabamba B, Dahlqvist G, Sempoux C, Lanthier N, Shindano T, Van Den Neste $E_{1}$ Horsmans Y. Occult HBV reactivation induced by ibrutinib treatment: a case report. Acta Gastroenterol Belg 2015;78:424426.

6. O'Brien $S$, Jones JA, Coutre $S E$, Mato AR, Hillmen P, Tam C, Österborg A, Siddiqi T, Thirman MJ, Furman RR, Ilhan O, Keating MJ, Call TG, Brown JR, Stevens-Brogan M, Li Y, Clow F, James DF, Chu AD, Hallek M, Stilgenbauer S. Ibrutinib for patients with relapsed or refractory chronic lymphocytic leukaemia with 17p deletion (RESONATE-17): a phase 2, open-label, multicentre study. Lancet Oncol 2016;17:1409-1418.

7. Herishanu $Y$, Katchman $H$, Polliack $A$. Severe hepatitis $B$ virus reactivation related to ibrutinib monotherapy. Ann Hematol 2017;96:689-690.

8. Hammond SP, Chen K, Pandit A, Davids MS, Issa NC, Marty FM. Risk of hepatitis $B$ virus reactivation in patients treated with ibrutinib. Blood 2018;131:1987-1990.

๑Copyright 2020 by Turkish Society of Hematology

Turkish Journal of Hematology, Published by Galenos Publishing House

Address for Correspondence/Yazışma Adresi: Gülşen İskender, MD, Dr. Abdurrahman Yurtaslan Ankara Oncology

Training and Research Hospital, Clinic of Infectious Diseases and Clinical Microbiology, Ankara, Turkey

Phone : +903125053304818

E-mail: golshan1669@hotmail.com ORCID: orcid.org/0000-0001-7619-1366
Received/Geliş tarihi: May 7, 2019

Accepted/Kabul tarihi: April 3, 2020

DOI: 10.4274/tjh.galenos.2020.2019.0180 